\title{
The Glass Slide Extraction System Snap Card Improves Non-Invasive Prenatal Genotyping in Pregnancies with Antibodies
}

\author{
Thomasz Adamczyk $^{\mathrm{a}}$ Andrea Doescher ${ }^{\mathrm{b}}$ Paul V. Haydock ${ }^{\mathrm{c}}$ Russ Aldrich ${ }^{\mathrm{c}}$ \\ Eduard K. Petershofen ${ }^{b}$ Thomas H. Müller ${ }^{d}$ \\ ${ }^{a}$ Medical Hospital 'Links der Weser', Gesundheit Nord, Department Internal Medicine, Bremen, Germany; \\ ${ }^{b}$ German Red Cross Blood Transfusion Service NSTOB, Institute Oldenburg, Germany; \\ 'Blood Cell Storage, Inc., Seattle, WA, USA; \\ ${ }^{\mathrm{d}}$ German Red Cross Blood Transfusion Service NSTOB, Institute Springe, Germany
}

\section{Keywords}

Cell-free DNA · Non-invasive prenatal genotyping ·

DNA extraction

\section{Summary}

Background: Determination of fetal blood groups in maternal plasma samples critically depends on adequate pre-analytical steps for optimal amplification of fetal DNA. We compared the extraction of cell-free DNA by binding on a glass surface (BCSI SNAPTM Card) with an automated system based on bead technology (MagnaPure compact $\left.{ }^{\mathrm{TM}}\right)$. Methods: Maternal blood samples from 281 pregnancies (7th-39th week of gestation) with known antibodies were evaluated in this study. Both the SNAP card and the MagnaPure method were applied to isolate DNA in order to directly compare the amplification in a single base extension assay and/or real-time PCR. Results: The mean concentration of total DNA obtained by the SNAP card $(33.8 \mathrm{ng} / \mu \mathrm{l})$ exceeded more than twofold that of MagnaPure extraction (15.7 $\mathrm{ng} / \mu \mathrm{l}$ ). SNAP card-extracted samples allowed to detect 3.7 single nucleotide polymorphisms (SNPs) versus 2.5 SNPs in MagnaPure extracts to control for traces of fetal DNA. This difference is highest for samples from 7th-13th week of gestation. Conclusion: The SNAP card system improves DNA extraction efficacy for prenatal diagnosis in maternal blood samples and provides an at least

Thomasz Adamczyk and Andrea Doescher have equally contributed to this manuscript. eightfold higher total amount of DNA for the ensuing analysis. Its advantage is most evident for samples from early stages of pregnancy and thus especially valuable for pregnancies with antibodies.

(c) 2015 S. Karger GmbH, Freiburg

\section{Introduction}

Fetal red blood cell (RBC) antigens are relevant in the pathologic involvement of maternal alloantibodies causing hemolytic disease of the fetus (HDF) or newborn (HDN). For diagnostic procedures, traces of fetal DNA circulating in the plasma of pregnant women are nowadays used for determination of blood groups of the fetus [1]. This non-invasive approach introduces a valuable alternative to invasive procedures, e.g. amniocentesis or collection of fetal blood, provided that the validity of the non-invasive diagnosis is proven. The reliability of non-invasive RHD typing with realtime PCR was investigated in large studies during the past decade [2-13]. The majority of the studies focused on screening of RHDnegative pregnant women to assess the need for anti-D-prophylaxis during pregnancy and collected samples after the 20th week of gestation [14-20]. A valid result in fetal genotyping may, however, be clinically meaningful for the diagnostic monitoring of pregnancies as early as 7th-13th week of gestation, especially if antibodies are already detectable in the maternal serum. A negative result in fetal blood group genotyping from maternal blood samples remains inconclusive unless the presence of adequate amounts of

\begin{tabular}{ll}
\hline KARGER & $\begin{array}{l}\text { (2) } 2015 \text { S. Karger GmbH, Freiburg } \\
1660-3796 / 15 / 0426-0379 \$ 39.50 / 0\end{array}$ \\
Fax +4976145207 14 & $\begin{array}{l}\text { Accessible online at: } \\
\text { Information@Karger.com } \\
\text { www.karger.com }\end{array}$ \\
www.karger.com/tmh
\end{tabular}


Table 1. Investigated blood group systems and known antibodies / antibody titer of tested samples
Fig. 1. SNAP card system for binding of cfDNA to the glass surface.

\begin{tabular}{|c|c|c|c|c|c|c|}
\hline \multirow[t]{2}{*}{ Blood group } & \multirow[t]{2}{*}{ Samples } & \multicolumn{3}{|c|}{ First antibody } & \multicolumn{2}{|c|}{ Second antibody } \\
\hline & & specifity & samples & titer, range & specifity & titer, range \\
\hline \multicolumn{7}{|c|}{7 th-13th week $(n=28)$} \\
\hline \multirow[t]{2}{*}{ RHD } & 18 & anti-D & 16 & $1-32,768$ & anti-C & $1-256$ \\
\hline & & & & & anti-K & 1024 \\
\hline KEL 1 & 8 & anti-K & 6 & $1-2,048$ & & \\
\hline RHc & 1 & anti-c & 1 & 64 & & \\
\hline RHE & 1 & anti-E & 1 & 16 & & \\
\hline \multicolumn{7}{|c|}{14 th-24th week $(n=208)$} \\
\hline \multirow[t]{3}{*}{ RHD } & 136 & anti-D & 60 & $1-65,536$ & anti-C & $1-512$ \\
\hline & & & & & anti-E & $1-32$ \\
\hline & & & & & anti-Jk(a) & $1-8$ \\
\hline KEL 1 & 27 & anti-K & 21 & $1-8,192$ & anti-Jk(a) & $1-64$ \\
\hline \multirow[t]{3}{*}{ RHE } & 18 & anti-E & 16 & $1-2,048$ & anti-c & $1-8$ \\
\hline & & & & & anti-Jk(a) & $1-128$ \\
\hline & & & & & anti-S & $1-128$ \\
\hline \multirow[t]{3}{*}{ RHc } & 12 & anti-c & 12 & $1-512$ & anti-K & $1-1,024$ \\
\hline & & & & & anti-E & $1-64$ \\
\hline & & & & & anti-S & $1-8$ \\
\hline $\mathrm{FY}^{\star} \mathrm{A}$ & 6 & anti-Fy(a) & 2 & $1-512$ & & \\
\hline RHC & 3 & anti-C & 3 & $1-32$ & anti-S & 1 \\
\hline $\mathrm{JK}^{*} \mathrm{~A}$ & 2 & anti-Jk(a) & 2 & $1-8$ & & \\
\hline MNS 1 & 2 & anti-M & 1 & 2 & & \\
\hline MNS 3 & 2 & anti-S & 2 & $1-64$ & & \\
\hline \multicolumn{7}{|c|}{$\geq 25$ th week $(n=45)$} \\
\hline \multirow[t]{2}{*}{ RHD } & 22 & anti-D & 16 & $1-4,096$ & anti-C & $1-64$ \\
\hline & & & & & anti-E & $1-8$ \\
\hline RHE & 10 & anti-E & 8 & $1-1,024$ & anti-c & $1-64$ \\
\hline KEL 1 & 3 & anti-K & 2 & $1-256$ & & \\
\hline \multirow[t]{3}{*}{ RHc } & 5 & anti-c & 4 & $1-128$ & anti-K & $1-512$ \\
\hline & & & & & anti-S & $1-1,024$ \\
\hline & & & & & anti-Fy(a) & 1 \\
\hline MNS 1 & 3 & anti-M & 3 & $1-8$ & & \\
\hline MNS 3 & 1 & anti-S & 1 & $1-32$ & & \\
\hline $\mathrm{FY}^{\star} \mathrm{A}$ & 1 & anti-Fy(a) & 1 & $1-512$ & & \\
\hline
\end{tabular}
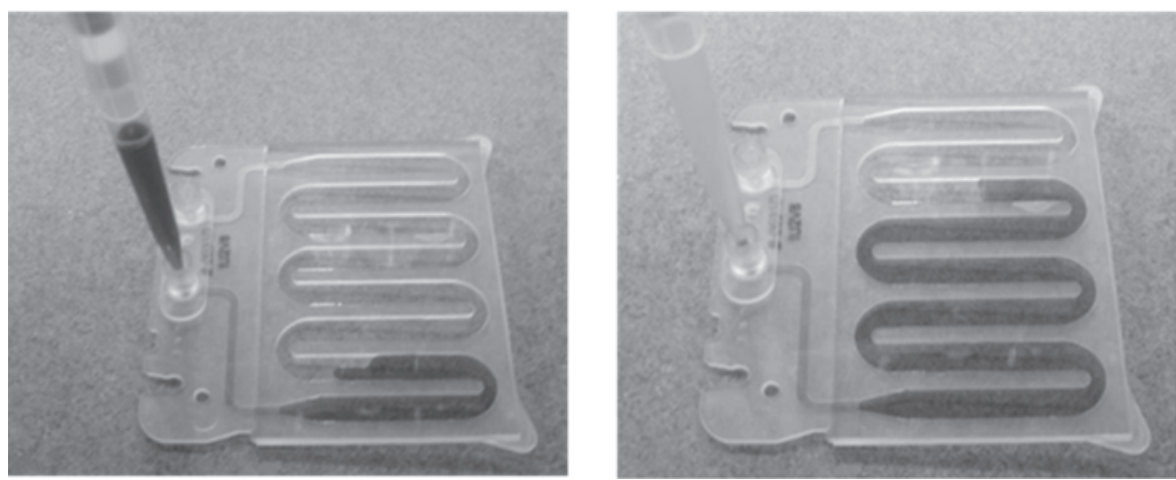

fetal DNA is demonstrated for each individual sample. A valid control for cell-free fetal DNA (cffDNA), neither depending on the gender of the fetus nor requiring a paternal control sample, is essential to fully exploit the potential of methods. Deletion/insertion polymorphisms and single nucleotide polymorphisms (SNPs) are used to discriminate between fetal and maternal DNA on a qualita- tive basis $[21,22]$. Insufficient amplification of cffDNA could occur due to problems with the effectiveness of DNA extraction, especially if the cffDNA concentration in the maternal plasma is very low.

Thus, quality of a specific DNA extraction technology affects the analytical performance of the diagnostic method. Different 
Table 2. Comparison of plasma-DNA extraction with MagnaPure and SNAP card technique

\begin{tabular}{|c|c|c|c|c|}
\hline & \multirow[t]{2}{*}{ All samples $(\mathrm{n}=281)$} & \multicolumn{3}{|l|}{ Week of gestation } \\
\hline & & 7 th-13th $(\mathrm{n}=28)$ & 14 th-24th $(\mathrm{n}=208)$ & $\geq 25$ th $(\mathrm{n}=45)$ \\
\hline DNA concentration, ng/ $\mu \mathrm{l}$ (range) & $15.7(4.9-87.5)$ & $13.6(5.8-25.6)$ & $15.8(4.9-87.5)$ & $17.0(10.1-23.9)$ \\
\hline Mean number of informative SNPs & 2.6 & 1.7 & 2.8 & 2.1 \\
\hline Mean peak height (SBE) & 1,253 & 998 & 1,269 & 1,308 \\
\hline Ct value & $36.8(\mathrm{n}=176)$ & $37.3(\mathrm{n}=18)$ & $37.0(\mathrm{n}=136)$ & $35.5(n=22)$ \\
\hline \multicolumn{5}{|l|}{ SNAP card } \\
\hline DNA concentration, $\mathrm{ng} / \mu \mathrm{l}$ (range) & $33.8(17.1-159.1)$ & $32.9(19.6-93.0)$ & $33.5(17.1-159.1)$ & $36.3(18.1-134.4)$ \\
\hline Mean number of informative SNPs & 3.7 & 3.3 & 3.9 & 2.9 \\
\hline Mean peak height (SBE) & 1,596 & 1,750 & 1,633 & 1,455 \\
\hline \multicolumn{5}{|l|}{ qPCR (RHD only) } \\
\hline Mean fetal DNA yield (\% of MagnaPure extraction) & $116.2(1.4-357.6)$ & $143.5(28.0-336.6)$ & $117.7(1.4-357.6)$ & $87.6(20.6-248.5)$ \\
\hline
\end{tabular}

technologies for extraction of maternal plasma, e.g. binding on spin columns or magnetic particles, have been evaluated for noninvasive prenatal blood group genotyping [23, 24].

DNA extraction from cell-free plasma by binding to the surface of a glass slide introduces an innovative approach for this purpose [25]. The SNAP card consists of an S-shaped plastic channel sandwiched by two glass slides. The sample can be flowed through the channel allowing contact between the sample and the flat glass surfaces to which the nucleic acids will bind (fig. 1).

We, therefore, compared this new method with our routine procedure based on magnetic particles to investigate plasma samples from 281 pregnant women with known antibodies or suspect of antibodies due to pregnancies in the past.

\section{Material and Methods}

\section{Samples and DNA Preparation}

EDTA-anticoagulated blood samples from 281 pregnant women (9th-36th week of gestation) were sent to our laboratory for routine non-invasive typing of fetal blood groups (table 1). Plasma was prepared according to Lo et al. [1]. DNA was extracted in parallel from $500 \mu \mathrm{l}$ of plasma using the MagnaPure large volume DNA isolation kit (MagnaPure compact ${ }^{\mathrm{TM}}$, Roche Diagnostics, Grenzach-Whylen, Germany) and the BCSI SNAP card. (Blood Cell Storage Inc. Seattle, WA, USA). The binding time for cell-free DNA (cfDNA) on the glass surface of the SNAP card varied from $18-24 \mathrm{~h}$ followed by $2 \times 3$ automated wash steps with buffer I and II and 10 min air-drying of the card. The final elution volume was $200 \mu \mathrm{l}$ (SNAP card) and $50 \mu \mathrm{l}$ (MagnaPure), respectively.

Genomic DNA from maternal samples was isolated with the PureGeneD Kit according to the manufacturers' instructions (PureGene Blood Core Kit B; QIAgen, Hilden, Germany).

\section{Quantification of the Total DNA Concentration}

Total DNA yield and purity of the extracted DNA was examined by UVspectroscopy (NanoDrop 1000; NanoDrop Technologies, Kisker, Steinfurt, Germany).

\section{SNP Detection}

DNA from 281 plasma samples (fetal DNA and maternal DNA for comparison) was screened for RHD exons 3, 4, 5 and 7 in a multiplex PCR setting in- cluding 52 SNPs divided into 4 primer pools as described previously [21]. SBE products were identified due to dye and size with the GeneScan method in an ABI 310 (Applied Biosystems, Foster City, CA, USA) and analyzed with GenMapper $^{\mathrm{TM}}$ software (version 4.0; Applied Biosystems) using the maximum-signal method for peak normalization.

Real-Time PCR

cfDNA from MagnaPure and SNAP card extraction was tested in duplicates for the presence of $R H D$ exon 10 as reported in detail elsewhere [21]. For calculation of cffDNA, standard curves were included in each qPCR run. Determination of $\%$ fetal DNA yield was done similar to Clausen et al. [23]

\section{Results}

The comparison of both methods for DNA extraction was based on maternal samples from 281 pregnancies: 28 from a pregnancy at week 7-13 of gestation, 208 from week 14-24 of gestation, and 45 from week $\geq 25$ of gestation. The concentration of total DNA in the eluates extracted in parallel from identical samples by both methods was measured. The quantitative PCR to detect RHD exon 10 was performed only in those samples $(\mathrm{n}=176)$ known from their initial investigation to be RHD-positive. All maternal blood samples $(\mathrm{n}=281)$ were typed for 52 SNPs with single base extension. The results are summarized in table 2 .

\section{DNA Extraction}

The extraction of cfDNA by binding to a glass surface has been compared to our standard automated magnetic beads technique. The mean concentration of total DNA for all samples extracted with the SNAP card was $33.8 \mathrm{ng} / \mu \mathrm{l}$ (range 17.1-159.1 ng/ $\mu \mathrm{l}$ ) compared to $15.7 \mathrm{ng} / \mu \mathrm{l}$ (range $4.9-87.5 \mathrm{ng} / \mu \mathrm{l}$ ) using magnetic particles. The substantially higher DNA extraction yield of SNAP card-extracted samples was confirmed for all samples, independent of the week of gestation. The extraction purity, characterized as ratio $260 / 280 \mathrm{~nm}$, was 1.8 or higher for SNAP card preparation and varied between 1.3 and 1.5 for MagnaPure assay (data not shown). 

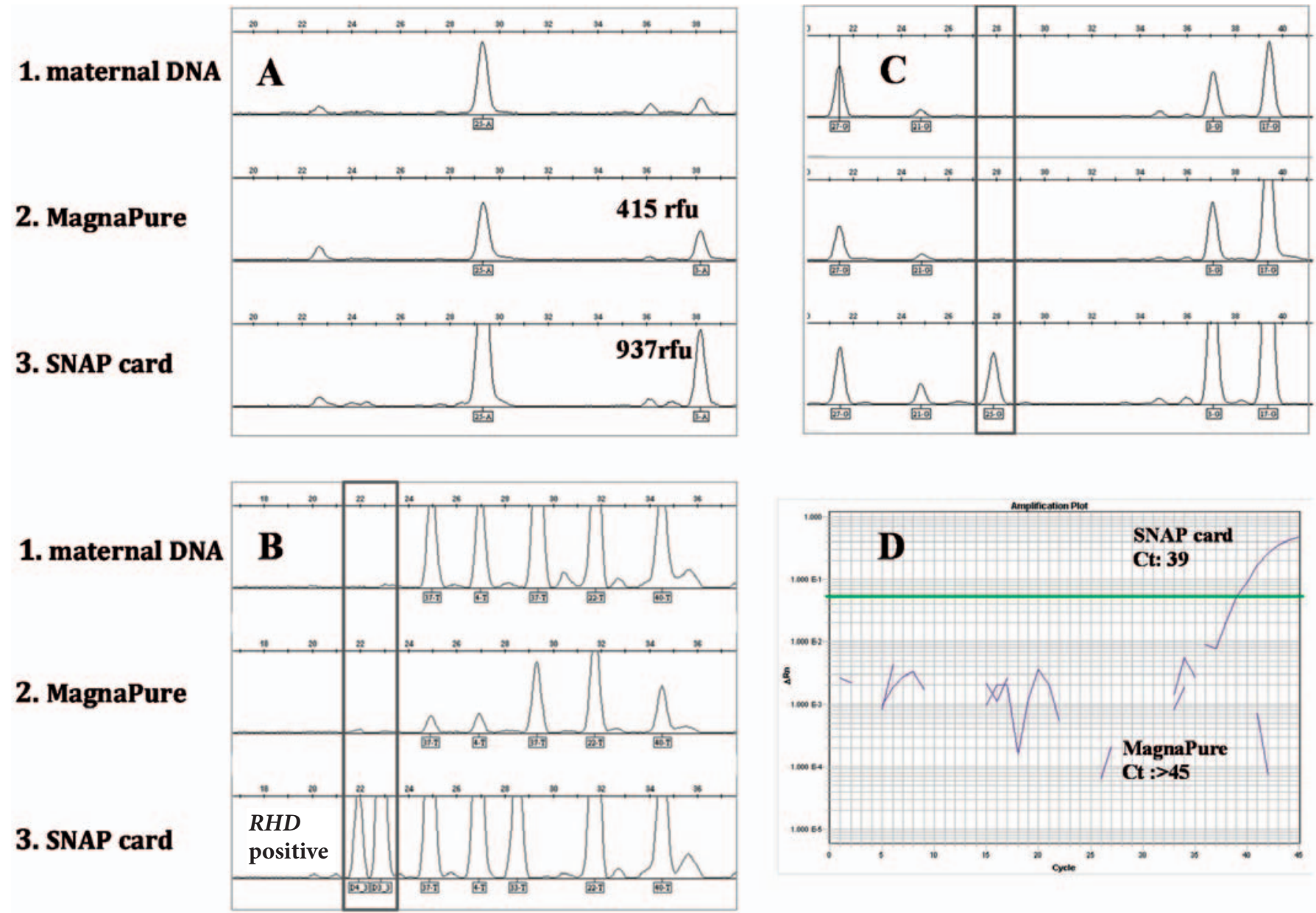

Fig. 2. Single base extension assay for determination of paternal SNPs and real-time PCR for the detection of $R H D$-specific sequences (12th week of gestation). A Higher peaks of SNAP card DNA ( $937 \mathrm{rfu}$ ) compared to MagnaPure extraction ( $415 \mathrm{rfu}$ ). B RHD-positive results for SNAP card sample, MagnaPure and maternal sample were D-negative. C Positive internal control in SNAP card sample; no signal in MagnaPure extracted DNA. D Real-time PCR with positive results for SNAP card DNA.

\section{Single Base Extension}

Single base extension assays serving as gender-independent internal controls showed higher (fig. 2A) and/or more peaks for paternal SNPs in the SNAP card-extracted samples (fig. 2B,C). The number of informative SNPs calculated for all samples was 3.7 in cfDNA from SNAP card compared to 2.6 after MagnaPure extraction. Samples from week 7-13 s of gestation had a mean of 3.3 informative SNPs in extracts prepared by SNAP card versus 1.7 for extracts obtained by magnetic bead technology. The mean difference in peak height examined for all samples and 52 SNPs was 343 relative fluorescence units (rfu). The mean peak height difference for all samples collected in the 1st trimenon was $752 \mathrm{rfu}$, decreasing to 364 for samples in the 2nd and 147 in the 3 rd trimenon.

\section{Real-Time PCR}

A difference of 0.5-1.1 was observed for threshold cycles (Ct values) in real-time amplification of RHD exon 10 comparing samples extracted with either method when a positive result was obtained. The mean yield of cffDNA (\%) for all samples was 116.2 ( $p<0.0001)$ with the highest value found in samples from the 1st trimenon (table 2). 14 MagnaPure-extracted samples (7th-13th week of gestation: $\mathrm{n}=3$; 14th-24th week of gestation: $\mathrm{n}=11$ ) failed in detection of RHD exon 10 while their SNAP card counterparts showed positive results.

\section{Discussion}

Non-invasive prenatal genotyping is an elegant approach to determine the fetal blood group genotype in pregnancies with known antibodies and at risk of HDN. The pre-analytical steps are essential for the success of the downstream applications, e.g. real-time PCR or fragment length analysis. In addition to the transport of the samples from the gynecologist to the laboratory [26] and the preparation of plasma, the extraction of cfDNA affects at least the sensitivity of the genotyping method [23, 24]. In addition, different extraction methods show different yields in cfDNA and cffDNA from plasma [23].

The SNAP card system bases on the capturing of DNA on untreated flat glass slides in the presence of chaotropic salts. The sys- 
tem is automated with washing and elution steps, and only cell lyses and proteinase treatment of the sample have to be done manually, with a hand-on time of approximately $10 \mathrm{~min}$. Special experiences of the operator are not necessary.

We designed a study to systematically evaluate this extraction technology for non-invasive prenatal genotyping. Maternal plasma samples stored at $-80^{\circ} \mathrm{C}$ up to 96 months were introduced into this study and were compared to our standard DNA extraction system for prenatal genotyping [20]. These systems have been optimized to detect the presence of both the RHD gene and sufficient amounts of cffDNA.

The results demonstrate the advantages of the extraction of cfDNA from plasma using glass slides. The SNAP card system provides both a higher concentration as well as a higher absolute yield of total nucleic acids. In respect to the different elution volume of the methods, the absolute yield of DNA was fourfold higher with the SNAP card procedure. A mean amount of $6.76 \mu \mathrm{g}$ total DNA was isolated by the SNAP card system in comparison to $0.79 \mu \mathrm{g}$ total DNA extracted by the MagnaPure procedure. The quality of the total nucleic acids, indicated by a $260 / 280 \mathrm{~nm}$ ratio of $\geq 1.8$, was better in SNAP card technique. Interestingly, the higher ratio did not affect the results of the real-time PCR. In contrast, the Ct values of MagnaPure-extracted samples were lower than the SNAP card counterparts $(0.5-1.1)$. Since both samples were tested in the identical real-time PCR run, the Ct values may be the result of a lower qPCR efficiency because of different composition of elution buffers of both extraction methods. Nevertheless, the mean yield of cffDNA (\%) was significantly higher in samples extracted with the SNAP card, especially in samples of the 1 st trimenon.

Both the number and the height of single base extension peaks were higher in DNA samples prepared with the SNAP card method. Calculated for all samples, the number of single base extension peaks, serving as internal controls for cffDNA, was 3.7 (SNAP card) and 2.6 (MagnaPure). Interestingly, samples from the 7th-13th week of gestation provided 3.3 informative SNPs when using glass-bound DNA compared to 1.7 for magnetic bead-bound DNA. In addition, the internal controls in this subgroup showed higher values for SNAP card DNA (MagnaPure $998 \mathrm{rfu}$; SNAP card 1,750 rfu).

An example is given in figure 2 for a pregnancy at 12 th week of gestation and an initial anti-D antibody of 2,048 rfu. In contrast to the MagnaPure extraction, the SNAP card DNA provided valid RHD typing results based on successful real-time PCR and single base extension assays. Such a failure of the typing with our standard extraction method in contrast to the SNAP card system was observed in 3/18 samples from the 1 st trimenon.

In our study, $94 \%$ of the samples collected from gestational week 7-13 were from women with at least one antibody. Our results emphasize the benefit of the glass slide extraction method in early pregnancies.

\section{Acknowledgement}

We acknowledge the expert technical assistance of Claudia Vogt and Simone Gnoth.

\section{Disclosure Statement}

The authors declare that they have no conflicts of interest relevant to this manuscript.

\section{References}

1 Lo YMD, Corbetta N, Chamberlain PF, Rai V, Sargent IL, Redman CWG, Wainscoat JS: Presence of fetal DNA in maternal plasma and serum. Lancet 1997;350: 485-487.

2 Bischoff FZ, Nguyen DD, Marquez-Do D, Moise KJ Jr, Simpson JL, Elias S: Noninvasive determination of fetal RhD status using fetal DNA in maternal serum and PCR. J Soc Gynecol Investig 1999;6:64-69.

3 Brojer E, Zupanska B, Guz K, Orzinska A, Kalinska A: Noninvasive determination of fetal RHD status by examination of cell-free DNA in maternal plasma. Transfusion 2005;45:1473-1480.

4 Faas BH, Beuling EA, Christiaens GC, von dem Borne AE, van der Schoot CE: Detection of fetal RHD-specific sequences in maternal plasma. Lancet 1998;352: 1196.

5 Gautier E, Benachi A, Giovangrandi Y, Ernault P, Olivi M, Gaillon T, Costa J-M: Fetal RhD genotyping by maternal serum analysis: a two-year experience. Am J Obstet Gynecol 2005; 192:666-669.

6 Geifman-Holtzman O, Grotegut CA, Gaughan JP: Diagnostic accuracy of noninvasive fetal $\mathrm{Rh}$ genotyping from maternal blood - a meta-analysis. Am J Obstet Gynecol 2006;195:1163-1173.
Hromadnikova I, Vechetova L, Vesela K, Benesova B, Doucha J, Vlk R: Non-invasive fetal RHD and RHCE genotyping using real-time PCR testing of maternal plasma in RhD-negative pregnancies. J Histochem Cytochem 2005;53:301-305.

8 Minon JM, Gerard C, Senterre JM, Schaaps JP, Foidart JM: Routine fetal RHD genotyping with maternal plasma: a four-year experience in Belgium. Transfusion 2008;48:373-381.

$\checkmark$ Nelson M, Eagle C, Langshaw M, Popp H, Kronenberg H: Genotyping fetal DNA by non-invasive means: extraction from maternal plasma. Vox Sang 2001;80: $112-116$.

10 Randen I, Hauge R, Kjeldsen-Kragh J, Fagerhol MK: Prenatal genotyping of RHD and SRY using maternal blood. Vox Sang 2003;85:300-306.

11 Rouillac-Le Scielour C PP, Gillot R, et al: Large-scale pre-diagnosis study of fetal RHD genotyping by PCR on plasma DNA from RhD-negative pregnant women. Mol Diagn 2004;8:23-31.

12 Van der Schoot CE, Soussan AA, Koelewijn J, Bonsel G, Paget-Christiaens LGC, de Haas M: Non-invasive antenatal RHD typing. Transfus Clin Biol 2006;13:5357.
Zhang J, Fidler C, Murphy MF, Chamberlain PF, Sargent IL, Redman CW, Hjelm NM, Wainscoat JS, Lo YM: Determination of fetal RhD status by maternal plasma DNA analysis. Ann N Y Acad Sci 2000;906: 153-155.

14 Clausen FB, Krog GR, Rieneck K, Nielsen LK, Lundquist R, Finning K, Dickmeiss E, Hedegaard M, Dziegiel $\mathrm{MH}$ : Reliable test for prenatal prediction of fetal $\mathrm{RhD}$ type using maternal plasma from $\mathrm{RhD}$ negative women. Prenat Diagn 2005;25:1040-1044.

15 Finning K, Martin P, Summers J, Massey E, Poole G, Daniels G: Effect of high throughput RHD typing of fetal DNA in maternal plasma on use of anti-RhD immunoglobulin in $\mathrm{RhD}$ negative pregnant women: prospective feasibility study. BMJ 2008;336:816-818.

16 Finning KM, Martin PG, Soothill PW, Avent ND: Prediction of fetal D status from maternal plasma: introduction of a new noninvasive fetal RHD genotyping service. Transfusion 2002;42:1079-1085.

17 Lucy Raymond F, Whittaker J, Jenkins L, Lench N, Chitty LS: Molecular prenatal diagnosis: the impact of modern technologies. Prenat Diagn 2010;30:674-681.

18 Muller SP, Bartels I, Stein W, Emons G, Gutensohn K, Kohler M, Legler TJ: The determination of the fetal D status from maternal plasma for decision making on $\mathrm{Rh}$ prophylaxis is feasible. Transfusion 2008;48:2292-2301. 
19 Rijnders RJ, Christiaens GC, Bossers B, van der Smagt JJ, van der Schoot CE, de Haas M: Clinical applications of cell-free fetal DNA from maternal plasma. Obstet Gynecol 2004;103:157-164.

20 Turner MJ, Martin CM, O'Leary JJ: Detection of fetal Rhesus D gene in whole blood of women booking for routine antenatal care. Eur J Obstet Gynecol Reprod Biol 2003; 108:29-32.

-21 Doescher A, Petershofen EK, Wagner FF, Schunter M, Muller TH: Evaluation of single-nucleotide polymorphisms as internal controls in prenatal diagnosis of fetal blood groups. Transfusion 2013;53:353-362.
22 Page-Christiaens GC, Bossers B, Van Der Schoot CE, De Haas M: Use of bi-allelic insertion/deletion polymorphisms as a positive control for fetal genotyping in maternal blood. Ann N Y Acad Sci 2006;1075:123129.

Clausen FB, Krog GR, Rieneck K, Dziegiel MH: Improvement in fetal DNA extraction from maternal plasma. Evaluation of the NucliSens Magnetic Extraction system and the QIAamp DSP Virus Kit in comparison with the QIAamp DNA Blood Mini Kit. Prenat Diagn 2007;27:6-10.
24 Ordonez E, Rueda L, Canadas MP, Fuster C, Cirigliano $\mathrm{V}$ : Evaluation of sample stability and automated DNA extraction for fetal sex determination using cell-free fetal DNA in maternal plasma. Biomed Res Int 2013; 2013:195363.

25 Nanassy OZ, Haydock PV, Reed MW: Capture of genomic DNA on glass microscope slides. Anal Biochem 2007;365:240-245.

26 Muller SP, Bartels I, Stein W, Emons G, Gutensohn K, Legler TJ: Cell-free fetal DNA in specimen from pregnant women is stable up to 5 days. Prenat Diagn 2011; 31:1300-1304. 